\title{
PROSES TRANSAKTIF, INTERAKSI ANTAR AKTOR AGEN TRANSFER DALAM PEMBANGUNAN LOKAL
}

\author{
Transactive Process, Interaction Between Actors of Transfer Agents \\ within Local Development
}

\section{Muhammad Taufiq ${ }^{1,2}$, Suhirman ${ }^{1}$ dan Benedictus Kombaitan ${ }^{1}$}

Diterima: 14 Mei 2019

Disetujui: 1 April 2020

\begin{abstract}
Abstrak: Perencanaan sebagai alat pengambilan keputusan mendapat intervensi dari aktoraktor yang terlibat di dalamnya, melalui wahana deliberasi yang merupakan perencanaan transaktif, dialog tatap muka antar perencana sebagai agen transfer dan masyarakat. Keadaan itu berdampak pada ketidaksesuaian antara kebijakan prioritas penggunaan anggaran yang ditetapkan di tingkat lokal terhadap pedoman pelaksanaan yang telah ditetapkan pemerintah pusat. Pertanyaan muncul bagaimana interaksi antar aktor terjadi dalam proses transaktif. Artikel ini mengevaluasi interaksi antar aktor yang terlibat dalam proses transaktif, yang terjadi saat perencanaan program kegiatan pembangunan lokal. Evaluasi dilakukan terhadap kasus program dana desa di Indonesia, melalui analisa deskripsi evaluatif dan literatur. Kajian bertujuan untuk memberikan pemahaman tentang interaksi antar aktor agen transfer pada saat terjadinya deliberasi di tingkat lokal. Hasil menunjukkan terjadinya interaksi antar agen transfer melalui praktik dominasi gagasan melalui wahana deliberasi partisipatif, yang cenderung menekankan dominasi pihak tertentu dalam penentuan prioritas kebijakan penggunaan anggaran.
\end{abstract}

Kata kunci: agen transfer, perencanaan transaktif, program dana desa di Indonesia

Abstract: Planning as a decision-making tool got intervention from the actors involved in it, through deliberation which is transactive planning and face-to-face dialogue between planners as transfer agents and the community. This situation has resulted in a mismatch between the priority policies for using the budget set at the local level and the implementation guidelines set by the central government. Questions arise how interactions between actors occurred in a transactive process. This article evaluates the interaction between involved actors in the transactive process, which occurs during a practice of local development planning program activity. Evaluations were carried out on village fund program cases in Indonesia, through qualitative approach analysis. The study aims to provide an understanding of the interactions between transfer agent actors during deliberation at the local level. The results show that the interaction between transfer agents conduct through the practice of dominating ideas, which tend to emphasize the dominance of certain parties in prioritizing budget use policies.

Keywords: transactive planning, transfer agent, village fund program in Indonesia

\footnotetext{
${ }^{1}$ Sekolah Arsitektur, Perencanaan dan Pengembangan Kebijakan, Institut Teknologi Bandung. ${ }^{2}$ Pemerintah Kabupaten Langkat, Provinsi Sumatera Utara.
} 


\section{PENDAHULUAN}

Perencanaan wilayah di tingkat lokal melibatkan interaksi antar aktor dalam penentuan kebijakan prioritas kegiatan. Prioritas kegiatan tersebut idealnya mengacu pada prioritas kegiatan yang ditetapkan oleh pemerintah pusat, serta disesuaikan dengan kearifan lokal dan keinginan masyarakat lokal. Penentuan prioritas kebijakan dilakukan melalui wahana deliberasi, melibatkan perencana dan masyarakat sebagai bentuk proses transaktif. Namun, interaksi antar aktor berdampak pada ketidaksesuaian antara prioritas kegiatan di tingkat lokal dan nasional. Participatory budgeting sebagai salah satu bentuk pengelolaan program pembiayaan di tingkat lokal, mengedepankan pembangunan wilayah dengan tahapan perencanaan penentuan prioritas kebijakannya melalui hasil musyawarah di tingkat lokal. Implementasi kegiatannya bersifat padat karya yang dikerjakan oleh warga setempat. Implementasi participatory budgeting mendatangkan manfaat atas kesesuaian antara keinginan masyarakat dengan pembangunan nasional, namun pada kondisi tertentu cenderung mengaburkan kepentingan nasional karena adanya intervensi dari komunitas tersebut terhadap keinginan di tingkat lokal yang tidak sesuai dengan pedoman yang telah ditetapkan. Prioritas kegiatan yang dihasilkan oleh deliberasi perencanaan pembangunan wilayah di tingkat lokal cenderung tidak sesuai dengan prioritas penggunaan anggaran yang telah ditetapkan pemerintah pusat. Praktiknya pada pengembangan wilayah di tingkat lokal pedesaan melibatkan interaksi antara perencana dan masyarakat, yang keseluruhannya merupakan aktor-aktor berkepentingan sebagai agen transfer.

Adanya indikasi bahwa kebijakan perencanaan wilayah di tingkat lokal didorong oleh interaksi antar aktor terlibat didalamnya, sebagai bentuk proses transaktif yang terjadi pada saat deliberasi (musyawarah perencanaan desa). Studi tentang participatory budgeting di tingkat lokal pedesaan selama ini masih membahas pada tatanan intensitas partisipasi masyarakat, kolaborasi antar aktor, pemaparan empiris pencapaiannya dalam mememenuhi fasilitas publik, serta pemaparan empiris tujuannya dalam mengatasi kesenjangan antara pembangunan kota dan desa (Bland, 2011; Cabannes \& Ming, 2014; Krenjova \& Raudla, 2018). Di sisi lain juga mengartikannya sebagai praktik relasi kekuasaan dan politik aktif warga negara, dimana masyarakat diberikan hak untuk menentukan kebijakan prioritas dalam penggunaan anggaran hingga nominal yang dibutuhkan (Fung \& Wright, 2001; Johansen \& Chandler, 2015; Kuruppu et al., 2016). Namun, sejauh ini belum sepenuhnya menjelaskan bagaimana praktik interaksi antar aktor berperan dalam mencapai efektivitas perencanaan sehingga terjadinya kesesuaian antara kebijakan prioritas penggunaan anggaran yang ditetapkan di tingkat lokal terhadap pedoman pelaksanaan yang telah ditetapkan pemerintah pusat.

Melalui tinjauan teori prosedural perencanaan, praktik deliberasi perencanaan wilayah di tingkat lokal merupakan bentuk proses transaktif yang mengedepankan dialogis, transfer pengetahuan, menuntut transparansi, akuntabilitas dan demokratis, sebagai media yang diharapkan dapat mengambil jalur tengah untuk mencapai keterpaduan antara perencana dan masyarakat (Friedmann, 1973, 2011; Hudson, dkk., 1979). Perencanaan transaktif adalah upaya untuk menjembatani perbedaan pandangan (communication gap) antara pengetahuan teknis dari perencana dengan pengetahuan lokal dari masyarakat (Friedmann, 1973, hlm. 171, 2011, hlm. 19). Pendekatan ini bersifat trasaksional (Taufiq, Kombaitan, \& Putro, 2018), dimana dalam deliberasi perencana berkontribusi pada pengetahuan keahlian dan komunitas lokal berkontribusi pada pengetahuan pengalaman untuk mencapai pembelajaran bersama sebagai landasan pembuatan keputusan (Khirfan, 2011). Pada perkembangannya, deliberasi yang terjadi cenderung dipengaruhi oleh interaksi antar aktor yang terlibat di dalamnya. Bagaimana interaksi antar aktor terjadi dalam proses transaktif? Penelitian ini diperlukan untuk memberikan pemahaman tentang interaksi antar aktor agen transfer pada saat terjadinya deliberasi di tingkat lokal.

Artikel ini mengevaluasi interaksi antar aktor yang terlibat dalam proses transaktif, yang terjadi saat perencanaan program kegiatan pembangunan lokal pedesaan. Melalui 
ilustrasi studi kasus pengelolaan program dana desa di Indonesia. Sejak tahun 2015 pemerintah Indonesia telah melakukan desentralisasi fiskal yang ambisius kepada pemerintah desa dengan mengalokasikan sebesar $10 \%$ dari anggaran pendapatan dan belanja negara (APBN) untuk pembiayaan penyelenggaraan program tersebut. Program ini adalah bentuk pembiayaan desa, bertujuan untuk meningkatkan kesejahteraan dan pemerataan pembangunan melalui peningkatan pelayanan publik, memajukan perekonomian, mengatasi kesenjangan pembangunan, serta memperkuat masyarakat desa sebagai subjek dari pembangunan. Namun, pada implementasinya sarat dengan ketidak sesuaian antara kebijakan prioritas penggunaan anggaran yang ditetapkan di tingkat desa terhadap prioritas penggunaan anggaran yang telah ditetapkan oleh pemerintah pusat. Hal ini cenderung dipengaruhi oleh interaksi antar aktor terlibat yang belum efektif saat pengambilan keputusan di tingkat lokal.

\section{METODE}

Analisa penelitian ini dilakukan melalui deskripsi evaluatif literatur dengan mengkombinasikan beberapa gagasan yakni teori perencanaan transaktif (Friedmann, 1973, 2011), deliberasi partisipatif (Forester, 1999; Innes \& Booher, 2003), serta pengalaman penulis sebagai aparatur di Pemerintah Daerah Kabupaten Langkat sejak 2008. Selanjutnya dievaluasi melalui ilustrasi studi kasus program dana desa di Indonesia, sebagai praktik perencanaan pembangunan wilayah lokal pedesaan yang cenderung dilakukan secara participatory budgeting (Fung \& Wright, 2001).

\section{HASIL}

Program dana desa (DD) merupakan dana transfer dari pemerintah pusat kepada pemerintah desa melalui pemerintah kota/ kabupaten, sebagai bentuk pembiayaan kewenangan lokal skala desa seperti pemerintahan, pembangunan dan pemberdayaan masyarakat. DD bertujuan untuk meningkatkan kesejahteraan dan pemerataan pembangunan desa melalui peningkatan pelayanan publik di desa, memajukan perekonomian desa, mengatasi kesenjangan pembangunan antar desa serta memperkuat masyarakat desa sebagai subjek dari pembangunan. Penganggarannya dibebankan kepada anggaran pendapatan dan belanja negara (APBN) sebesar $10 \%$ per tahun sehingga merupakan isu nasional terkait dengan pengelolaannya. Nominal dana desa yang telah dikucurkan pada masing-masing tahun anggaran sebesar IDR 20,766 T di tahun 2015, IDR 46,982 T di tahun 2016 dan IDR $60 \mathrm{~T}$ di tahun 2017, sedangkan untuk tahun 2018 telah dianggarkan sejumlah IDR $60 \mathrm{~T}$ sama seperti tahun sebelumnya (Kemenkeu, 2017).

Pemanfaatan dana desa setiap tahunnya berpedoman kepada aturan prioritas penggunaan dana desa yang ditetapkan pemerintah pusat, namun pada praktiknya masih terdapat penggunaan dana desa di luar bidang prioritas (Kemenkeu, 2017). Beberapa prioritas kegiatan hasil deliberasi di tingkat lokal yang tidak sesuai diantaranya tumpang tindihnya kegiatan dana desa terhadap program/ kegiatan dari pemerintah pusat/ provinsi/ kabupaten, ketidaksesuaian porsi prioritas pembangunan fisik, alokasi tidak berimbang, tidak tepat sasaran, serta pengalokasian dana desa untuk kepentingan pribadi elit lokal, hingga adanya penyalahgunaan wewenang dan penyelewengan terhadap dana desa.

Pada tahun anggaran 2018 program DD ditujukan pada pemenuhan: 1) Bidang pembangunan desa, diarahkan untuk pengadaan, pembangunan, pengembangan dan pemeliharaan; dan 2) Bidang pemberdayaan masyarakat desa, diarahkan untuk pengembangan kapasitas dan ketahanan masyarakat desa, serta pengembangan sistem informasi dan pelayanan sosial. Pengelolaan dana desa dilakukan oleh pemerintah desa setempat beserta masyarakatnya. Disisi lain terdapat pihak eksternal pemerintah desa yang pada artikel ini disebut dengan agen transfer yang bertugas mengawasi dan membantu desa 
dalam mewujudkan pengelolaan program dana desa agar sesuai dengan aturan yang telah ditetapkan oleh pemerintah pusat. Agen transfer terdiri dari pemerintah desa itu sendiri, perwakilan kecamatan, perwakilan kabupaten, serta pendamping desa yang mengarahkan agar pengelolaan dana desa sesuai dengan tata kelola pelaksanaannya.

Pengelolaan DD berlangsung secara partisipatif, biasa dikatakan dengan metode penganggaran partisipatif atau participatory budgeting (PB). PB muncul pada akhir 1980an di beberapa kotamadya Brasil, yang berawal dari kemenangan politik Partai Pekerja di Porto Alegre, Ibu Kota Negara Bagian Rio Grande do Sul di Brasil. Pelaksanaannya sebagai referensi utama praktik keberhasilan $\mathrm{PB}$ melalui program-program pembangunan yang berbasis kepentingan masyarakat lokal (Fung \& Wright, 2001). Penganggaran partisipatif merupakan bentuk pengambilan kebijakan dalam perencanaan pengembangan wilayah melalui penggunaan anggaran pembiayaan yang penetapannya dilakukan melalui partisipasi masyarakat. Masyarakat diberikan wewenang untuk menentukan programprogram kegiatan apa yang ingin dilaksanakan, hingga nominal pembiayaannya. Metode ini sebagai langkah untuk meningkatkan partisipasi masyarakat dalam bentuk perencanaan tipikal bottom-up. Namun pada implementasinya cenderung memiliki kendala seperti ketidaksesuaian program yang dianggarkan terhadap prioritas penggunaan anggaran yang telah ditetapkan pemerintah pusat, karena menerapkan ideologi komunikatif (proses transaktif) atau minimnya pengaruh pemerintah dalam strategi pembuatan keputusan yang terjadi pada saat deliberasi (Voogd \& Woltjer, 1999).

\section{DISKUSI: DETERMINASI PERENCANAAN TRANSAKTIF TERHADAP INTERAKSI ANTAR AGEN TRANSFER DALAM PEMBANGUNAN LOKAL}

Pengelolaan dana desa merupakan proses transaktif yang terjadi melalui praktik deliberasi partisipatif. Desentralisasi fiskal kepada pemerintah desa melalui pengelolaan dana desa efektivitasnya tergantung pada saat terjadinya deliberasi penentuan prioritas penggunaan anggaran. Desentralisasi fiskal melalui implementasi dana desa untuk meningkatkan pertumbuhan dan pemerataan pembangunan (Widodo, 2017), telah meningkatkan partisipasi masyarakat melalui wahana deliberasi seperti musyawarah pembangunan di tingkat dusun hingga tingkat desa, partisipasi dalam mengikuti bimbingan teknis, dan sosialisasi. Adanya program dana desa yang mulai di implementasikan tahun 2015 secara umum telah meningkatkan partisipasi masyarakat dalam berperan serta pada pembangunan lokal (Daraba, 2017; Luthfi, dkk., 2017; Mamelo, dkk., 2016; Tumbel, 2017). Namun, penelitian yang dilakukan tentang pengelolaan dana desa tersebut selama ini belum menjelaskan terjadinya ketidaksesuaian antara prioritas kebijakan yang dihasilkan di tingkat lokal terhadap pedoman pelaksanaannya. Hal ini cenderung disebabkan oleh tidak bekerjanya proses transaktif pada saat deliberasi perencanaan pembangunan wilayah.

Perencanaan transaktif sebagai bagian dari teori prosedural perencanaan berada pada tatanan tipe perencanaan komunikatif. Disamping itu, juga terdapat berbagai bentuk tipe perencanaan komunikatif lainnya seperti perencanaan komunikatif (Forester, 1982, 1989), perencanaan kolaboratif (Healey, 1997, 2003), perencanaan partisipatif (Forester, 1999), dan perencanaan konsensus (Innes, 1996; Woltjer, 2000). Adapun tipe-tipe perencanaan tersebut memiliki karakteristik dan penekanannya masing-masing (Tabel 1.). Penelitian ini cenderung menggunakan perencanaan transaktif karena kesesuaian dari karakteristiknya yang menggunakan dialog tatap muka melalui wahana deliberasi antar perencana selaku agen transfer dan masyarakat. Perencanaan transaktif cenderung membahas adanya interaksi antar agen transfer (Khirfan, 2011, hlm. 529). Melalui sudut pandang bahwa pengelolaan dana desa mengutamakan terjadinya deliberasi partisipatif dan transfer ilmu pengetahuan antar transfer agent, serta terjadinya mutual learning, maka kajian ini akan cenderung mengarah pada pemahaman perencanaan transaktif. 
Pendekatan perencanaan transaktif berfokus pada pengalaman utuh kehidupan masyarakat, mengungkap isu-isu kebijakan yang harus ditangani. Perencanaan dilakukan melalui tatap muka dengan masyarakat yang berdampak langsung terhadap hasil keputusan (kebijakan). Perencanaan meminimalisir survei lapangan dan analisis data, namun lebih banyak dilakukan melalui dialog antar-pribadi yang ditandai dengan proses belajar bersama (Hudson dkk., 1979, hlm. 389).

Perencanaan program dana desa melibatkan berbagai aktor yang berasal dari berbagai kalangan dan unsur kepentingan masing-masing. Sebut saja masyarakat (sebagai klien), berada dalam wadah deliberasi dengan mengusung kepentingan pembangunan yang cenderung diharapkan agar sesuai dengan kepentingan pribadinya atau kelompoknya. Di sisi lain ada pemerintah desa, perwakilan kecamatan, perwakilan kabupaten dan pendamping lokal desa (sebagai perencana) yang memiliki kepentingan agar hasil deliberasi sesuai dengan pedoman yang telah ditetapkan. Kondisi ini berdampak pada interaksi antar aktor pada saat terjadinya deliberasi penentuan kebijakan prioritas kegiatan. Transfer agent adalah aktor-aktor yang berperan pada proses transaktif yang memiliki latar belakang pengetahuan masing-masing untuk saling memahami melalui musyawarah pembangunan desa (musrenbangdes), bimbingan teknis dan sosialisasi, yang mana pada penelitian ini disebut sebagai wahana deliberasi.

Tabel 1. Perbandingan tipologi perencanaan komunikatif.

\begin{tabular}{|c|c|c|c|c|c|}
\hline $\begin{array}{l}\text { Karakteristik } \\
\text { perencanaan }\end{array}$ & Transaktif & Komunikatif & Kolaboratif & Partisipatif & Konsensus \\
\hline Penggagas & $\begin{array}{l}\text { Friedmann (1973, } \\
\text { 2011) }\end{array}$ & $\begin{array}{l}\text { Forester } \\
(1982,1989)\end{array}$ & $\begin{array}{l}\text { Healey } \\
(1997,2003)\end{array}$ & $\begin{array}{l}\text { Forester } \\
(1999)\end{array}$ & $\begin{array}{l}\text { Innes (1996), } \\
\text { Woltjer (2000) }\end{array}$ \\
\hline Penekanan & $\begin{array}{l}\text { Kesesuaian antara } \\
\text { teori dan tindakan } \\
\text { Pembelajaran } \\
\text { sosial } \\
\text { Transfer } \\
\text { pengetahuan }\end{array}$ & $\begin{array}{l}\text { Kejelasan } \\
\text { informasi }\end{array}$ & Koordinasi & Keikutsertaan & $\begin{array}{l}\text { Persamaan } \\
\text { persepsi }\end{array}$ \\
\hline Pencapaian & $\begin{array}{l}\text { Mutual learning } \\
\text { Deliberasi }\end{array}$ & Komunikasi & Deliberasi & Deliberasi & $\begin{array}{l}\text { Komitmen } \\
\text { Deliberasi }\end{array}$ \\
\hline Efektivitas & $\begin{array}{l}\text { Transfer } \\
\text { pengetahuan }\end{array}$ & $\begin{array}{l}\text { Minimalisisr } \\
\text { distorsi }\end{array}$ & $\begin{array}{l}\text { Pelibatan } \\
\text { stakeholder }\end{array}$ & & \\
\hline Perencana & $\begin{array}{l}\text { Agen perubahan, } \\
\text { Negosiator }\end{array}$ & Mediator & Fasilitator & Fasilitator & Negosiator \\
\hline
\end{tabular}

Sumber: Penulis, 2019.

Deliberasi merupakan proses pengarahan yang dilakukan perencana kepada klien. Didalamnya terdapat komponen transfer pengetahuan atau training secara dialogis tatap muka berkenaan keputusan yang akan diambil bersama. Melalui deliberasi, masyarakat termasuk pihak yang mendefinisikan masalah dan tujuan, serta identifikasi alternatif rencanan/ kebijakan dan implementasi (dalam kasus-kasus tertentu seperti pengelolaan program dana desa). Dengan demikian masyarakat mendapat andil sebagai salah satu pihak perumus kebijakan, namun tidak sebagai penentu, karena kebijakannya diambil melalui musyawarah perencanaan. Tulisan akademis pada teori perencanaan komunikatif cenderung berkonsentrasi pada rasionalitas komunikatif dalam forum deliberasi publik, biasanya karena terkait dengan berbagai metode interaksi partisipatif dalam sistem perencanaan dan pemerintahan lokal (Huxley, 2000, hlm. 373). Hal ini juga sebagai salah satu pembahasan pada penelitian, yakni keterkaitan antar agen transfer (selaku pemerintah) untuk mendeliberasi kebijakan yang ada (dalam kasus ini adalah anggaran pendapatan dan belanja desa/ APBDes), agar program yang dirancancang berpedoman pada aturan yang telah ditetapkan pemerintah pusat (dalam kasus program dana desa). Namun untuk terjadinya kondisi tersebut, maka akan melalui proses interaksi antara perencana 
pemerintah dan klien (masyarakat/ komunitas). Dengan beragamnya kepentingan di masyarakat desa, sehingga agen transfer bertugas untuk memastikan agar dokumen perencanaan pembangunan tersebut (APBDes) yang salah satunya berisi tentang penggunaan dana desa sesuai dengan peruntukannya. Dari uraian tersebut, maka pada kasus ini proses transaktif sebagai unsur utama perencanaan komunikatif karena dominannya interaksi antar aktor.

\section{Dominasi gagasan sebagai interaksi antar aktor dalam praktik deliberasi}

Keterlibatan publik dapat dilihat melalui peran serta dan kehadirannya dalam setiap tahapan pengelolaan dana desa. Secara umum pengelolaan dana desa di bagi pada beberapa tahapan (Gambar 1.), yakni 1) Perencanaan: Penentuan kegiatan dan anggaran pembiayaan, 2) Penatausahaan: Pengelolaan administrasi pembiayaan, 3) Pelaksanaan kegiatan, dan 4) Pelaporan dan pertanggungjawaban. Pada saat perencanaan sangat diperlukan partisipasi masyarakat karena merupakan penentuan program kegiatan yang akan disepakati untuk selanjutnya menjadi kebijakan penggunaan anggaran. Partisipasi pada identitas ini dapat dilihat melalui kehadiran, difokuskan agar tercapai keterwakilan dari setiap dusun. Adapun pada tahapan perencanaan dapat bervariasi, mulai dari musyawarah di tingkat dusun hingga tingkat desa. Perencanaan di tingkat dusun akan menjadi lebih alot dibanding dengan musyawarah di tingkat desa, karena di tingkat dusun, masyarakat yang terlibat akan menyusun rencana-rencana program kegiatan yang nantinya akan dibawa pada musyawarah di tingkat desa, untuk selanjutnyadi negosiasikan dan di kolaborasikan dengan rencana di tingkat dusun lainnya. Pada tahap perencanaan di tingkat dusun akan timbul prioritas kegiatan yang akan dilaksanakan, namun kegiatan ini masih tentatif dan sarat dengan ketidak sesuaian terhadap prioritas yang telah di tetapkan oleh pemerintah pusat. Hal ini diakibatkan minimnya transfer agent yang ada pada deliberasi di tingkat dusun.

Musyawarah penentuan program kegiatan di tingkat dusun umumnya dipandu oleh kepala dusun tanpa kehadiran perangkat desa lainnya, pendamping desa, perwakilan kecamatan dan perwakilan kabupaten, serta lebih mengedepankan kemauan tanpa adanya pengawasan yang intensif. Partisipasi pada perencanaan di tingkat dusun lebih mengedepankan kehadiran, kesesuaian dengan apa yang ingin dilakukan dan negosiasi internal masyarakat lokal dalam dusun tersebut. Pada perkembangan selanjutnya saat proses perencanaan di tingkat desa, selain kehadiran, tingkat negosiasi juga merupakan hal yang dominan karena merupakan penentuan kebijakan prioritas kegiatan dalam satu desa. Dalam arti setiap program akan saling kait mengait dengan kepentingan antar dusun, prioritas yang ditetapkan pemerintah pusat dan kecukupan pembiayaan. Pelibatan masyarakat pada musyawarah desa dapat ditandai dengan tingkat kehadiran, namun di sisi lain identitas dominasi gagasan adalah hal yang dominan berlangsung pada kegiatan ini karena berhubungan dengan penentuan kegiatan final untuk desa dan penganggaran pembiayaan, serta telah dihadiri oleh berbagai agen transfer. Pada tahap pelaksanaan, keterlibatan publik dilihat dari peran serta masyarakat sebagai pekerja dari pengadaan kegiatan pembangunan yang dilaksanakan, sebagaimana kegiatan-kegiatan yang didanai oleh program DD sebagian besar adalah pemenuhan sarana fisik dan pekerjanya adalah diprioritaskan untuk penduduk desa setempat.

Kajian menunjukkan bahwa proses transaktif yang terjadi khususnya pada deliberasi penentuan kebijakan prioritas, yakni pada saat musrenbangdes, menimbulkan interaksi yang meningkat hingga mencapai pada suatu kondisi dimana kecenderungan terjadinya dominasi gagasan yang dilakukan oleh masing-masing aktor. Identitas dominasi gagasan terjadi pada tahap penentuan prioritas program kegiatan baik di saat musyawarah pembangunan di tingkat dusun maupun di tingkat desa. Namun secara umum terjadi pada musyawarah di tingkat desa. Dominasi gagasan terjadi melalui proses transaktif antara perencana dengan masyarakat lokal dalam menentukan pilihan kegiatan, yang diarahkan 
agar sesuai dengan prioritas penggunaan anggaran yang ditetapkan pemerintah pusat. Pada tahap ini terjadi dominasi pihak tertentu dalam penentuan prioritas kebijakan, serta terjadi transfer pengetahuan antara agen transfer kepada masyarakat untuk membentuk pengetahuan organisasi agar mengarah kepada tujuan yang telah ditetapkan. Berbagai kepentingan yang melatar belakangi antara agen transfer dan masyarakat dilebur dalam deliberasi partisipatif untuk mendapatkan kebijakan yang sesuai. Pada momen ini masyarakat tidak sepenuhnya dapat dikatakan masyarakat yang memiliki tujuan sama, namun seharusnya dikatakan komunitas yang memiliki kepentingan. Maknanya adalah ketika kita menyebutkan istilah masyarakat berarti kita menganggap bahwa mereka memiliki satu kepentingan yang sama dalam melakukan deliberasi, namun hal itu bias karena mereka sendiri sebenarnya terdiri dari kelompok-kelmpok kepentingan yang tidak sepenuhnya homogen, sehingga terjadi politik atau kepentingan di dalam deliberasi. Maka kata masyarakat sebenarnya adalah bias karena cenderung mengartikan bahwa kepentingan pihak-pihak yang ada di dalamnya adalah sama. Hal ini yang menyebabkan adanya transfer pengetahuan dalam deliberasi partisipatif melalui identitas dominasi gagasan (Tabel 2.).

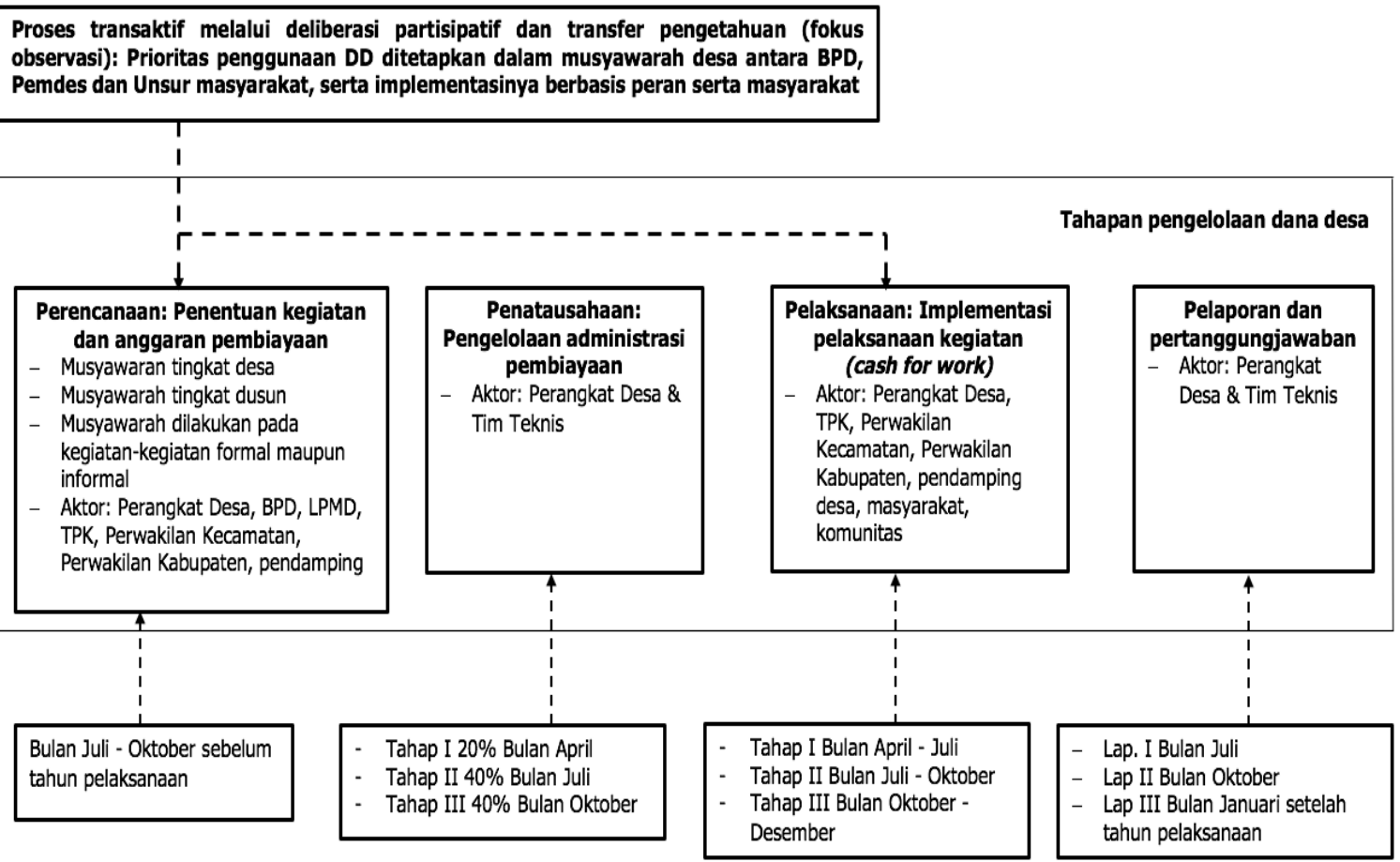

Gambar 1. Proses transaktif melalui deliberasi partisipatif pada tahapan pengelolaan dana desa

Tabel 2. Ringkasan Proses Transaktif sebagai Interaksi antar Aktor dalam Pengelolaan Program Dana Desa.

\begin{tabular}{llll}
\hline Identitas & $\begin{array}{l}\text { Deliberasi } \\
\text { partisipatif }\end{array}$ & Tipe transaktif & Hasil transaktif \\
\hline Dominasi gagasan & $\begin{array}{l}\text { Dominasi pihak } \\
\text { tertentu dalam } \\
\text { penentuan prioritas } \\
\text { kegiatan }\end{array}$ & Transfer pengetahuan & $\begin{array}{l}\text { Penciptaan nilai } \\
\text { organisasi }\end{array}$ \\
& & & \\
\hline
\end{tabular}

Sumber: Penulis, 2019. 
Pada perkembangan selanjutnya identitas dominasi gagasan akan menghasilkan penciptaan nilai organisasi yang direfleksikan melalui hasil keputusan atau kebijakan deliberasi (APBDes). Tidak ada ketentuan dan aturan yang mengikat terkait hasil keputusan musrenbangdes bilamana telah sesuai dengan pedoman yang ditetapkan atau tidak. Sehingga dengan demikian kesesuaian tersebut akan sangat bergantung pada efektifitas transfer agent dalam menggiring animo masyarakat agar memiliki pengetahuan bersama/ mutual learning yang searah dengan pengarahan yang diberikan. Di sisi lain, ada kecenderugan bahwa dominasi gagasan ini mengarah pada suatu bentuk relasi kekuasaan, dimana tipikal praktiknya (agonisme atau antagonisme) sangat dipengaruhi oleh budaya politik pedesaan bersangkutan. Ini mendukung argumen bahwa participatory budgeting tidak terpisahkan dari relasi kekuasaan, bahkan di level desa sekalipun (Fung \& Wright, 2001; Johansen \& Chandler, 2015; Kuruppu et al., 2016). Namun, disini dominasi kekuasaan tersebut dilihat sebagai bentuk intensitas yang mempengaruhi transfer pengetahuan antar aktor yang terlibat dalam deliberasi.

\section{KESIMPULAN}

Adanya ketidaksesuaian antara prioritas kebijakan yang dihasilkan di tingkat lokal dengan pedoman pelaksanaannya cenderung disebabkan oleh tidak bekerjanya proses transaktif pada saat deliberasi perencanaan pembangunan wilayah di tingkat lokal. Proses tersebut terjadi melalui interaksi antar aktor yang terlibat dengan membawa misinya masing-masing. Melalui wahana deliberasi, proses interaksi antar aktor tersebut mengerucut menjadi aktifitas dominasi gagasan. Dimana dominasi gagasan akan berlangsung dengan adanya transfer pengetahuan antar masing-masing aktor. Rekomendasi ditujukan terhadap penelitian selanjutnya tentang bagaimana terjadinya dominasi gagasan antar agen transfer dengan mengedepankan identitas-identitas yang ditimbulkannya secara empiris.

\section{PERNYATAAN RESMI}

Gagasan artikel ini sebelumnya disajikan pada Seminar Nasional Asosiasi Sekolah Perencana Indonesia (ASPI), Bogor, 28 Agustus 2018.

\section{DAFTAR PUSTAKA}

Bland, G. (2011). Supporting post-conflict democratic development? External promotion of participatory

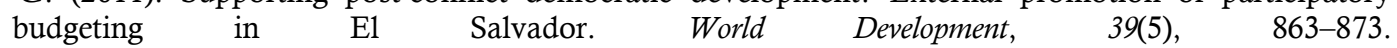
https://doi.org/10.1016/j.worlddev.2010.09.010

Cabannes, Y. (2004). Participatory budgeting: A significant contribution to participatory democracy. Environment and Urbanization, 16(1), 27-46. https://doi.org/10.1177/095624780401600104

Daraba, D. (2017). Pengaruh program dana desa terhadap tingkat partisipasi masyarakat di Kecamatan Galesong Utara Kabupaten Takalar. Sosiohumaniora, 19(1), 52-58.

Forester, J. (1982). Planning in the face of power. Journal of the American Planning Association, 48(1), 67-80. https://doi.org/10.1080/01944368208976167

Forester, J. (1989). Planning in the face of power. University of California Press.

Forester, J. (1999). The deliberative practitioner: Encouraging participatory planning processes. MIT Press.

Friedmann, J. (1973). Retracking America: A theory of transactive planning. Garden City, New York: Anchor Press.

Friedmann, J. (2011). Insurgencies: Essays in planning theory. Routledge.

Fung, A., \& Wright, E. O. (2001). Deepening democracy: Innovations in empowered participatory governance. Politics \& Society, 29(1), 5-41. https://doi.org/10.1177/0032329201029001002

Healey, P. (1997). Collaborative planning: Shaping places in fragmented societies. UBC Press.

Healey, P. (2003). Collaborative planning in perspective. Planning Theory, 2(2), 101-123.

Hudson, B. M., Galloway, T. D., \& Kaufman, J. L. (1979). Comparison of current planning theories: Counterparts and contradictions. Journal of the American Planning Association, 45(4), 387-398. https://doi.org/10.1080/01944367908976980 
Huxley, M. (2000). The limits to communicative planning. Journal of Planning Education and Research, 19(4), 369-377. https://doi.org/10.1177/0739456X0001900406

Innes, J. E. (1996). Planning through consensus building: A new view of the comprehensive planning ideal. Journal of the American Planning Association, 62(4), 460-472.

Innes, J. E., \& Booher, D. E. (2003). Collaborative policymaking: Governance through dialogue. Dalam M. A. Hajer \& H. Wagenaar (Ed.), Deliberative policy analysis (hlm. 33-59). Cambridge: Cambridge University Press.

Johansen, P. H., \& Chandler, T. L. (2015). Mechanisms of power in participatory rural planning. Journal of Rural Studies, 40, 12-20. https://doi.org/10.1016/j.jrurstud.2015.05.006

Kemenkeu. (2017). Buku saku dana desa. Jakarta: Kementerian Keuangan Republik Indonesia.

Khirfan, L. (2011). From Toronto to Amman: The cross-national transfer of planning knowledge. Planning Theory \& Practice, 12(4), 525-547. https://doi.org/10.1080/14649357.2011.626307

Krenjova, J., \& Raudla, R. (2018). Policy diffusion at the local level: Participatory budgeting in Estonia. Urban Affairs Review, 54(2), 419-447. https://doi.org/10.1177/1078087416688961

Kuruppu, C., Adhikari, P., Gunarathna, V., Ambalangodage, D., Perera, P., \& Karunarathna, C. (2016). Participatory budgeting in a Sri Lankan urban council: A practice of power and domination. Critical Perspectives on Accounting, 41, 1-17. https://doi.org/10.1016/j.cpa.2016.01.002

Luthfi, A., Rini, H. S., Gustaman, F. A., Arsal, T., \& Rochana, T. (2017). Partisipasi masyarakat dalam pengelolaan dan pemanfaatan dana desa di Desa Keji Kabupaten Semarang. Matra Pembaruan: Journal of Policy Innovation, 1(2), 121-130.

Mamelo, G. Y. R., Kalangi, L., \& Lambey, L. (2016). Analisis pelaksanaan dan penatausahaan dana desa pada desa-desa dalam wilayah Kecamatan Kotamobagu Timur, Kota Kotamobagu. Jurnal Riset Akuntansi Dan Auditing "Goodwill," 7(2), 148-159.

Taufiq, M., Kombaitan, B., \& Putro, H. P. H. (2018). CSR, suatu refleksi perencanaan transaktif: Perspektif filsafat ilmu pengetahuan. TATALOKA, 20(2), 136-147.

Tumbel, S. M. (2017). Partisipasi masyarakat dalam pengelolaan dana desa di Desa Tumaluntung Satu Kecamatan Tareran Kabupaten Minahasa Selatan. Politico: Jurnal Ilmu Politik, 6(1).

Voogd, H., \& Woltjer, J. (1999). The communicative ideology in spatial planning: Some critical reflections based on the Dutch experience. Environment and Planning B: Planning and Design, 26(6), 835-854. https://doi.org/10.1068/b260835

Widodo, I. (2017). Dana Desa dan Demokrasi dalam Perspektif Desentralisasi Fiskal. Politik Indonesia: Indonesian Political Science Review, 2(1), 65-85.

Woltjer, J. (2000). Consensus planning: The relevance of communicative planning theory in Dutch infrastructure development. Ashgate. 